University of Nebraska - Lincoln

DigitalCommons@University of Nebraska - Lincoln

\title{
Early weaning in Northern Great Plains beef cattle production
} systems: I. Performance and reproductive response in range beef cows

\author{
R.C. Waterman \\ richard.waterman@ars.usda.gov \\ T.W. Geary \\ USDA-ARS \\ J.A. Paterson \\ Montana State University \\ R.J. Lipsey \\ American Simmental Association
}

Follow this and additional works at: https://digitalcommons.unl.edu/usdaarsfacpub

Waterman, R.C.; Geary, T.W.; Paterson, J.A.; and Lipsey, R.J., "Early weaning in Northern Great Plains beef cattle production systems: I. Performance and reproductive response in range beef cows" (2012).

Publications from USDA-ARS / UNL Faculty. 1178.

https://digitalcommons.unl.edu/usdaarsfacpub/1178

This Article is brought to you for free and open access by the U.S. Department of Agriculture: Agricultural Research Service, Lincoln, Nebraska at DigitalCommons@University of Nebraska - Lincoln. It has been accepted for inclusion in Publications from USDA-ARS / UNL Faculty by an authorized administrator of DigitalCommons@University of Nebraska - Lincoln. 


\title{
Early weaning in Northern Great Plains beef cattle production systems: I. Performance and reproductive response in range beef cows is
}

\author{
R.C. Waterman ${ }^{\mathrm{a}, *}$, T.W. Geary ${ }^{\mathrm{a}}$, J.A. Paterson ${ }^{\mathrm{b}}$, R.J. Lipsey ${ }^{\mathrm{c}}$ \\ ${ }^{a}$ USDA-ARS, Fort Keogh Livestock and Range Research Laboratory, Miles City, MT 59301-4016, USA \\ ${ }^{\mathrm{b}}$ Department of Animal and Range Sciences, Montana State University, Bozeman, MT 59717, USA \\ c American Simmental Association, Bozeman, MT 59715, USA
}

\section{A R T I C L E I N F O}

Keywords:

AI

Beef cows

Early weaning

Natural service

Reproduction

\begin{abstract}
A B S T R A C T
A study was conducted to determine if early weaning spring born calves can be an alternative management strategy during drought and if early weaning facilitates rebreeding of young cows. Our objectives were to determine effects of early weaning at the start of breeding on cow body weight, body condition score, and reproductive performance with or without estrous synchronization and $\mathrm{AI}$ in two herds in the Northern Great Plains, USA. In Exp. 1 and 2, crossbred cows were stratified within cow age by postpartum interval, and calf sex, and were assigned within strata to one of two weaning treatments at the start of breeding when calves averaged 80-d of age: (1) early weaned (permanent calf removal); or (2) no weaning (calves suckled cows until normal weaning approximately 210-d of age). Cows in Exp. 1 were exposed to natural service whereas cows in Exp. 2 were exposed to estrous synchronization for AI using a CIDR for $7 \mathrm{~d}$ with $\mathrm{GnRH}$ at CIDR insertion and $\mathrm{PGF}_{2 \alpha}$ at CIDR removal followed by natural service. In Exp. 3, cows were stratified within breed by age, postpartum interval, calf sex, and AI sire and were assigned within strata to one of two weaning treatments at the start of breeding, as described for Exp. 1 and 2. Estrous cycles of all cows were synchronized for AI using one of two protocols including $14 \mathrm{~d}$ CIDR $+\mathrm{PGF}_{2 \alpha}$ $16 \mathrm{~d}$ following CIDR removal (primiparous cows) or a CIDR insert for $7 \mathrm{~d}$ with $\mathrm{GnRH}$ at CIDR insertion and $\mathrm{PGF}_{2 \alpha}$ at CIDR removal (multiparous cows). Cows in Exp. 2 and 3 were bred by AI approximately $12 \mathrm{~h}$ after observation of estrus or by timed AI at $80 \mathrm{~h}$ after $\mathrm{PGF}_{2 \alpha}$ concurrent administration of GnRH. Artificial insemination (Exp. 2), breeding season pregnancy rate, and day of conception was not influenced $(P>0.10)$ by weaning treatment for Exp. 1 and 2. However, early weaned cows in Exp. 3 had $12.0 \%$ greater $(P=0.03) \mathrm{AI}$ pregnancy rates and conception occurred $3.78 \mathrm{~d}$ earlier $(P=0.03)$ than normal weaned cows. At the time of normal weaning, cows that had their calves removed at early weaning were heavier and had greater body condition $(P<0.01)$ than normal weaned cows in each experiment. We conclude that early-weaning beef cows at the start of the breeding season improved BW gain and BCS allowing those females to enter winter in greater BCS then NW cows, but improvements in reproductive performance were inconsistent.
\end{abstract}

Published by Elsevier B.V.

\footnotetext{
USDA, Agricultural Research Service, Northern Plains Area, is an equal opportunity/affirmative action employer. All agency services are available without discrimination. This research was conducted under a cooperative agreement between USDA-ARS and the Montana Agricultural Experiment Station. Mention of a proprietary product does not constitute a guarantee or warranty of the product by USDA, Montana Agricultural Experiment Station, or the authors and does not imply its approval to the exclusion of other products that also may be suitable.

* Correspondence to: United States Department of Agriculture, Agricultural Research Service, Fort Keogh Livestock and Range Research Laboratory, 243 Fort Keogh Road, Miles City, MT 59301-4016, USA. Tel.: +1 406874 8208; fax: +1 4068748289.

E-mail address: richard.waterman@ars.usda.gov (R.C. Waterman).
} 


\section{Introduction}

Cow-calf producers may optimize beef cow performance by implementing early weaning of calves particularly during times when forage quantity and/or quality are insufficient to meet cow requirements (e.g., drought) or when there is concern about impacts of low body condition on subsequent reproductive success (especially young cows). Lactation stress during periods of drought can exhaust nutritional stores in beef cows resulting in BW loss and decreased reproductive performance.

Suckling delays the onset of estrus in beef cows (Short et al., 1972), and early weaning before the breeding season has shortened the postpartum anestrous period and increased pregnancy rates (Laster et al., 1973; Lusby et al., 1981). Primiparous heifers have benefited from higher planes of nutrition when compared to multiparous cows during the anestrous period (Hansen et al., 1982), which would also suggest a benefit to early weaning. Lactating cows consume more forage than gestating cows (Galindo-Gonzalez et al., 2007; Marston and Lusby, 1995) and research has shown for each $\mathrm{kg}$ increase in milk yield a $0.33-0.37 \mathrm{~kg}\left(R^{2}=0.52\right.$ and 0.64 , respectively) increase in daily forage dry matter intake (DMI) throughout lactation (Johnson et al., 2003). Thus indicating the removal of the demands of lactation early in the postpartum period should allow for the repartitioning of dietary nutrient towards maternal tissue and allow cows to be in greater body condition going into month where dietary forage is less nutrient dense (Waterman et al., 2007). Furthermore, the removal of lactational demands reduces intake demands and may conserve pasture resources that are valuable especially during extended drought conditions. Young cows ( 2 and 3-yr-olds) that are still partitioning nutrients for growth should benefit the most from early weaning strategies.

Reproductive protocols that induce estrous cycles are available for beef producers today that were not available 30 years ago. The objectives of this study were to determine effects of early weaning at the start of the breeding season compared to normal weaning at 7 months of age (Exp. 1) and the value of early weaning in association with applied reproductive strategies (Exp. 2 and 3) on reproductive performance, cow age, body weight (BW) gain, and body condition score (BCS) of beef cow herds in the Northern Great Plains, USA.

\section{Material and methods}

\subsection{Study sites}

The study was conducted at two locations in the Northern Great Plains, USA. For Exp. 1 and 2 the research was conducted at the USDA-ARS, Fort Keogh Livestock and Range Research Laboratory (LARRL), located approximately $1.6 \mathrm{~km}$ west of Miles City, MT $59301\left(46^{\circ} 22^{\prime} \mathrm{N}\right.$ $\left.105^{\circ} 5^{\prime} \mathrm{W}\right), \mathrm{USA}$, at an average elevation of $730 \mathrm{~m}$. Average annual precipitation is $340 \mathrm{~mm}$ with the majority occurring from April through September from convectional thunderstorms (Fig. 1). Predominant grass genera at this location included wheatgrass (Pascopyron), needlegrass
(Hesperostipa), and grama (Bouteloua) within a mixedgrass dominated rangeland (Küchler, 1964). The average annual forage standing crop at the study site is $870 \pm 14 \mathrm{~kg} / \mathrm{ha}$ (Grings et al., 2005). Average daily temperatures range from $-5{ }^{\circ} \mathrm{C}$ in January to $24^{\circ} \mathrm{C}$ in July with daily maximum temperatures occasionally exceeding $37{ }^{\circ} \mathrm{C}$ during summer and daily minimums occasionally dropping below $-40{ }^{\circ} \mathrm{C}$ during winter (WRCC, 2006).

For Exp. 3 the research occurred in Central Montana, approximately $5 \mathrm{~km}$ northeast of Judith Gap, MT 59453 $\left(46^{\circ} 41^{\prime} \mathrm{N} 109^{\circ} 45^{\prime} \mathrm{W}\right)$, USA, at an average elevation of $1270 \mathrm{~m}$. Annual precipitation for this region is $383 \mathrm{~mm}$ with the majority of that moisture accumulating from April through October (Fig. 1). Predominant forages in pastures at this location included wheatgrass (Pascopyron) and needlegrass (Hesperostipa) with slighter amounts of alfalfa (Medicago), grama (Bouteloua), junegrass (Koeleria), and bluegrass (Poa). Average daily temperatures, at this site, range from $-3{ }^{\circ} \mathrm{C}$ in February to $21^{\circ} \mathrm{C}$ in July with daily maximum temperatures occasionally exceeding $37{ }^{\circ} \mathrm{C}$ during summer and daily minimum temperatures occasionally dropping below $-40{ }^{\circ} \mathrm{C}$ during winter (WRCC, 2006).

\subsection{Animals, measurements and management}

The LARRL Institutional Animal Care and Use Committee approved all animal handling and experimental procedures utilized in the present studies. Three similar experiments were conducted; two at LARRL and a third in a commercial production situation, Judith Gap. Each experiment had approximately twice as many early weaned (EW; weaned at approximately 80-d of age) cows as normal weaned (Control) cows to balance calf weaning treatments. While normal weaned calves remained on their dam until time of normal weaning (approximately 7 months of age) early weaned calves (approximately 2.5 months of age) received one of the following diets: (1) $17.5 \% \mathrm{CP}$ (69\% RDP and $7.53 \mathrm{MJ} / \mathrm{kg} \mathrm{NEm}$ ) or (2) $17.5 \% \mathrm{CP}$ (57\% RDP and $7.69 \mathrm{MJ} / \mathrm{kg} \mathrm{NEm}$ ) from time of early to normal weaning.

In Exp. 1, crossbred cows (predominantly Angus $\times$ Hereford) at the LARRL location (2005) calved over a 87 d period from March 1, 2005 to May 27, 2005 (primiparous cows March 14, 2005 through May 6, 2005 with a mean of March 30, $2005 \pm 1.2 \mathrm{~d}$; multiparous cows March 1, 2005 through May 27, 2005 with a mean of April 25, $2005 \pm 0.9 \mathrm{~d})$ and were stratified within cow age by calf sex and age then randomly assigned within strata to one of two weaning treatments at the start of breeding. Cows $(n=338)$ had calves removed at the start of breeding ( $n=220 ; 78.1 \pm 0.96 \mathrm{~d}$ postpartum) or at normal weaning ( $n=118$; at approximately $210.5 \pm 0.96 \mathrm{~d}$ postpartum). Cows were bred by natural service (bull:cow ratio of $1: 23$ ) without synchronization for a 58 -d breeding season on July 5,2005 . Breeding pastures $(n=2)$ contained both early weaned cows and normal weaned cows (cows with calves still nursing) and cows were assigned to a breeding pasture that contained either Angus or Polled Hereford bulls to maximize heterosis. Each breeding pasture contained a similar number of early and normal weaned 


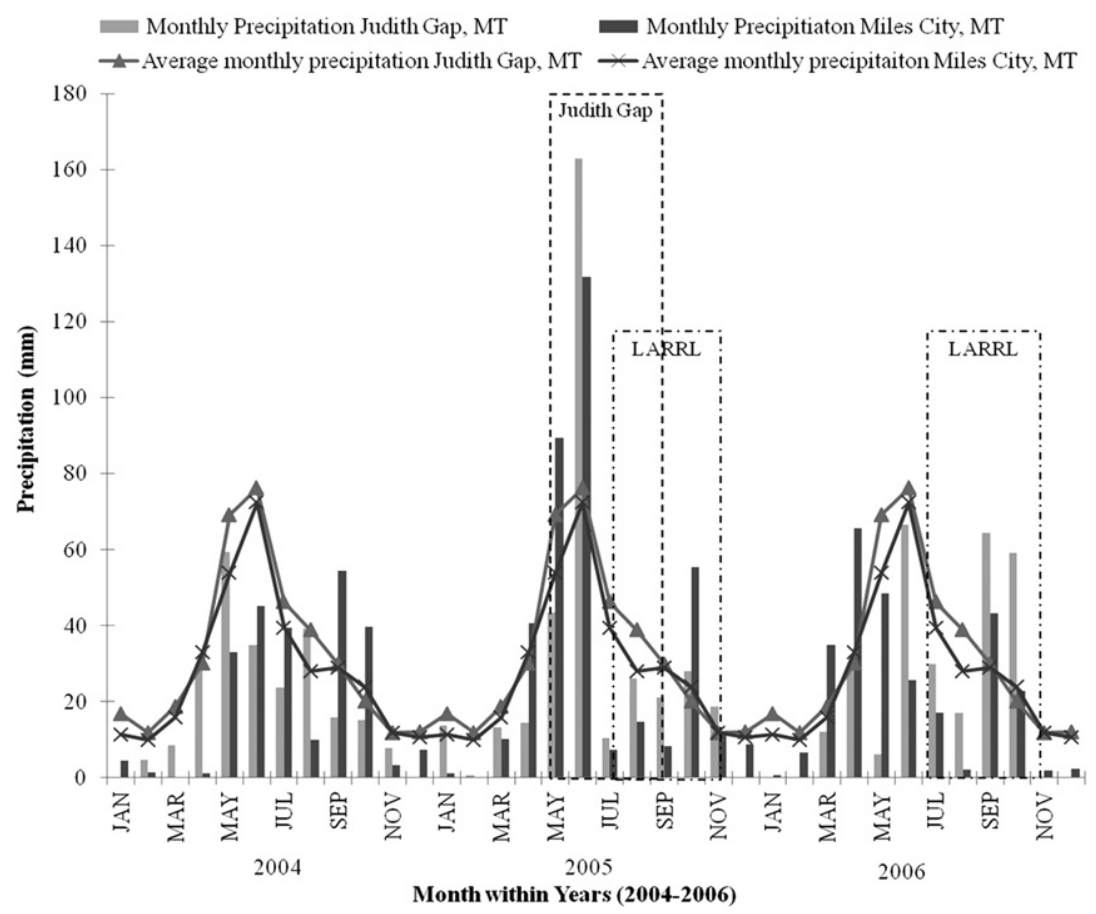

Fig. 1. Monthly precipitation between 2004 and 2006 within years (bars) and 57- and 70-year average (line) for Judith Gap and Miles City, MT, respectively. Dashed boxes indicate when each experiment took place [Judith Gap (May 9-September 19, 2005); Miles City (July 5-November 15, 2005); Miles City (July 10-November 20, 2006)]. Information obtained from Western Regional Climate Center (WRCC, 2006). These studies were conducted from May 2005 to November 2006.

cows. Pregnancy was diagnosed on day 58 and 133 after onset of breeding and date of conception estimated by transrectal ultrasonography using a $5 \mathrm{MHz}$ linear probe (Aloka, Wallingford, CT 06492, USA). Cow BW was measured and recorded at time of early and normal weaning along with BCS ( $1=$ emaciated to $9=$ extremely obese) which was assigned by 2 experienced technicians as described by Herd and Sprott (1986) and Wagner et al. (1988). Cow BW and BCS changes were calculated for the 133-d period (July 5 through November 15, 2005) between early and normal weaning and again prior to start of calving on March 4, 2006 (mean calving date April 25, $2006 \pm 0.65 \mathrm{~d})$.

In Exp. 2, the same cow herd was used in 2006 at LARRL and cows calved over a $80 \mathrm{~d}$ period from March 12 , 2006 to May 31, 2006 (primiparous cows March 12, 2006 through May 31, 2006 with a mean of March 29, $2006 \pm 1.2 \mathrm{~d}$; multiparous cows April 3, 2006 through May 31, 2006 with a mean of April 25, $2006 \pm 0.6 \mathrm{~d}$ ). Cows were stratified within cow age by calf sex and age then randomly assigned within strata to one of the two weaning treatments as described in Exp. 1. Cows $(n=322)$ had calves removed at the start of breeding on July 10 , 2006 ( $n=215 ; 83.0 \pm 0.85$ d postpartum) for EW treatment or at normal weaning $(n=107 ; 208.4 \pm 0.85$ d postpartum). Estrous cycles of all cows were synchronized for AI using a controlled intravaginal drug releasing insert (CIDR; Pfizer Animal Health, New York NY, 10017, USA) for $7 \mathrm{~d}$ with GnRH $(100 \mu \mathrm{g}$, i.m.; Fertagyl, Intervet Inc., Millsboro, DE 19966, USA) at CIDR insertion and PGF $_{2 \alpha}$ (25 mg, i.m.; ProstaMate, Teva Animal Health, Saint
Joseph, MO 64503, USA) at time of CIDR removal. Timing of early weaning coincided with the $\mathrm{PGF}_{2 \alpha}$ injection of the above protocol. Cows were observed for estrus continuously during daylight hours from $\mathrm{PGF}_{2 \alpha}$ injection until $72 \mathrm{~h}$ after $\mathrm{PGF}_{2 \alpha}$. Cows detected in estrus were inseminated approximately $12 \mathrm{~h}$ later. Cows not detected in estrus by $72 \mathrm{~h}$ after $\mathrm{PGF}_{2 \alpha}$ received timed AI with GnRH $\left(100 \mu \mathrm{g}\right.$, i.m.) at $80 \mathrm{~h}$ after $\mathrm{PGF}_{2 \alpha}$. To accurately measure cows bred by AI, herd bulls were placed with cows two weeks following AI and remained with cows until the end of a 50-d breeding season. Breeding pastures $(n=2)$ contained a similar number of early weaned (EW) and normal weaned (NW) cows. Cows were assigned to a breeding pasture that contained either Angus (bull:cow ratio of $1: 23$ ) or Polled Hereford (bull:cow ratio of $1: 22.5$ ) bulls to maximize heterosis. Pregnancy was diagnosed on day 59 and 115 after $\mathrm{AI}$ and date of conception estimated by transrectal ultrasonography as described above. Cow BW and BCS was collected as described above for the 133-d period (July 10 through November 20, 2006) between early and normal weaning and again on March 3 , 2007 just prior to the start of calving (mean calving date April 30, $2007 \pm 0.75 \mathrm{~d}$ ).

In Exp. 3, at the Judith Gap location (2005), Angus $(n=199)$ and Angus $\times$ Simmental $(n=158)$ cows calved over an $81 \mathrm{~d}$ period from January 2, 2005 to March 24, 2005 (primiparous cows January 2, 2005 through March 14,2005 with a mean of January 30, $2005 \pm 0.8 \mathrm{~d}$; multiparous cows January 2, 2005 through April 5, 2005 with a mean of February 26, $2005 \pm 0.8 \mathrm{~d}$ ). Cows were stratified within breed and age, then by calf sex, age, and AI sire 
before being randomly assigned within strata to one of the two weaning treatments as described in Exp. 1 and 2. Cows $(n=357)$ had calves removed at the start of breeding $(n=236 ; 77.3 \pm 0.90 \mathrm{~d}$ postpartum $)$ or at normal weaning ( $n=121 ; 211.8 \pm 0.90$ d postpartum). Cow BW was measured and recorded at time of early and normal weaning and BW change was evaluated over the 133-d period (May 9 through September 19, 2005). Estrous cycles of all cows were synchronized for AI using one of two protocols designed to maximize pregnancy rates to AI. Primiparous cows $(n=90)$ received a CIDR insert for $14 \mathrm{~d}$ with $\mathrm{PGF}_{2 \alpha}$ (25 mg, i.m.) $16 \mathrm{~d}$ following CIDR removal and multiparous cows $(n=267)$ received a CIDR insert for $7 \mathrm{~d}$ with GnRH $(100 \mu \mathrm{g})$ at CIDR insertion and $\mathrm{PGF}_{2 \alpha}$ (25 mg, i.m.) at CIDR removal. Like Exp. 2, timing of early weaning coincided with the $\mathrm{PGF}_{2 \alpha}$ injection of the above protocols. Estrous synchronization protocols were offset in primiparous and multiparous cows so that the $\mathrm{PGF}_{2 \alpha}$ injection in both groups occurred on the same date. Cows were observed for estrus continuously during daylight hours from $\mathrm{PGF}_{2 \alpha}$ injection until $72 \mathrm{~h}$ after $\mathrm{PGF}_{2 \alpha}$. Cows detected in estrus were inseminated approximately $12 \mathrm{~h}$ later. Cows not detected in estrus by $72 \mathrm{~h}$ after $\mathrm{PGF}_{2 \alpha}$ were time Al'ed with GnRH (100 $\mu$ g, i.m.) 80 h after PGF $2 \alpha$. Two weeks after AI, Angus bulls were placed with cows and remained with cows until the end of a 50-d breeding season. Primiparous cows (bull:cow ratio of $1: 31.3$ ) remained in a single breeding pasture for the duration of this study regardless of weaning treatment. Multiparous cows were pastured in two adjacent and similar breeding pastures according to weaning treatment (bull:cow ratio of 1:40 and 1:35.8 for early and normal weaned cows, respectively). Pregnancy was diagnosed on day 85 after $\mathrm{PGF}_{2 \alpha}$ injection and date of conception estimated by transrectal ultrasonography as described above. Cow BW was measured and recorded once at time of early and normal weaning and BW change was evaluated over the 133-d period (May 9 through September 19, 2005).

\subsection{Forage characteristics}

Rumen extrusa samples were analyzed (LARRL location only) to estimate and describe nutritional chemical composition of forages grazed by experimental cows. Diet extrusa samples were collected on July 26, and November 9, 2005 and on July 26, and November 13, 2006 representing the initial (EW) and ending (NW) nutritional characteristics of forage grazed (Table 1). Two ruminally cannulated cows were pasture grazed with experimental cows throughout the study. On day of extrusa sampling, ruminal contents from cannulated cows were evacuated and stored in 208-L plastic tubs, and ruminal walls were sponge dried to remove any residual moisture as described by Lesperance et al. (1960). After removal of ruminal contents, cows were released into experimental pastures and allowed to graze for 45-60 min. After grazing about, extrusa was recovered from the rumen and thoroughly mixed. An aliquot was saved for analysis and original ruminal contents were returned. Collected extrusa samples ( 1 from each cow) were frozen at $-20^{\circ} \mathrm{C}$, lyophilized, ground to pass a $2-\mathrm{mm}$ screen, and stored until analysis
Table 1

Forage extrusa nutrient composition collected from ruminally-cannulated cows grazing alongside experimental cows in Exp. 1 (2005) and Exp. 2 (2006) on rangelands in the Northern Great Plains, USA.

\begin{tabular}{|c|c|c|c|}
\hline \multirow[b]{2}{*}{ Item } & \multicolumn{3}{|c|}{ Extrusa collection } \\
\hline & \multicolumn{2}{|c|}{ Early weaning (Breeding) } & Normal weaning \\
\hline Year 1 (2005) & & $\mathrm{MJ} / \mathrm{kg} \mathrm{OM}$ & \\
\hline $\mathrm{DE}$ & 12.1 & & 9.2 \\
\hline \multirow[t]{2}{*}{ ME } & 10.0 & & 7.9 \\
\hline & & $\%$ & \\
\hline DM & 91.1 & & 91.9 \\
\hline $\mathrm{OM}$ & 86.2 & & 86.0 \\
\hline $\mathrm{CP}^{\mathrm{a}}$ & 9.1 & & 7.3 \\
\hline $\mathrm{NDF}^{\mathrm{a}}$ & 67.6 & & 72.3 \\
\hline $48 \mathrm{~h}$ OM digestibility & 69.4 & & 49.7 \\
\hline 96 h OM digestibility & 76.3 & & 59.5 \\
\hline 48 h NDF digestibility ${ }^{\mathrm{a}}$ & 66.3 & & 46.4 \\
\hline \multirow[t]{2}{*}{96 h NDF digestibility ${ }^{a}$} & 75.4 & & 57.6 \\
\hline & & $\% / \mathrm{h}$ & \\
\hline Rate of fiber digestion & 4.8 & & 4.9 \\
\hline Year 2 (2006) & & $\mathrm{MJ} / \mathrm{kg} \mathrm{OM}$ & \\
\hline $\mathrm{DE}$ & 11.7 & & 10.9 \\
\hline \multirow[t]{2}{*}{$\mathrm{ME}$} & 9.6 & & 8.8 \\
\hline & & $\%$ & \\
\hline DM & 91.0 & & 91.8 \\
\hline $\mathrm{OM}$ & 89.6 & & 86.7 \\
\hline $\mathrm{CP}^{\mathrm{a}}$ & 8.5 & & 7.9 \\
\hline $\mathrm{NDF}^{\mathrm{a}}$ & 67.4 & & 73.6 \\
\hline 48 h OM digestibility & 62.3 & & 58.5 \\
\hline 96 h OM digestibility & 73.7 & & 68.3 \\
\hline 48 h NDF digestibility & 66.7 & & 57.9 \\
\hline \multirow[t]{2}{*}{96 h NDF digestibility } & 75.4 & & 70.5 \\
\hline & & $\% / \mathrm{h}$ & \\
\hline Rate of fiber digestion & 4.7 & & 4.8 \\
\hline
\end{tabular}

${ }^{\text {a }}$ OM basis.

for dry matter (DM), organic matter (OM) by previously reported procedures (AOAC, 1990), and NDF (Goering and Van Soest, 1970). Sub-samples of ground extrusa were placed in glass square bottom jars with metal rod inserts and dried in a $60{ }^{\circ} \mathrm{C}$ oven for $12 \mathrm{~h}$. Upon removal from a drying oven, jars were capped with lids and subsequently placed on a roller grinder for $24 \mathrm{~h}$ (Mortenson, 2003). Nitrogen was determined by combustion techniques using a C-N analyzer (CE Elantech, Inc., Lakewood, NJ08701, USA). Nitrogen values were multiplied by 6.25 to obtain $\mathrm{CP}$, which was expressed on an OM basis.

To estimate diet digestibility, ground extrusa samples $(5 \mathrm{~g})$ were placed in duplicate Dacron bags $(10 \mathrm{~cm} \times$ $20 \mathrm{~cm}$; pore size $=53 \pm 10 \mu \mathrm{m}$; Ankom Technology Corp., Fairport, NY 14450, USA). These filled Dacron bags (4/cow) and a blank bag (1/cow) were placed into a $60 \mathrm{~cm} \times 60 \mathrm{~cm}$ zippered laundry bag with an attached cord and then placed into the rumen at specific times to allow for $96,48,24$, and $0 \mathrm{~h}$ of incubation. Amount of residue in the blank Dacron bag was subtracted from each sample bag collected at the same incubation time to correct for influx of particles during incubation. Upon removal from the rumen, at $0 \mathrm{~h}$, all bags were subjected to an initial rinse by submerging bags 3 times in a 19-L bucket. The 19-L bucket was filled with cold water to stop fermentation ( 0 - $h$ bags were not inserted into the rumen but were subjected to the rinsing in the 19-L bucket). Bags 
were stored in plastic zippered bags prior to being frozen at $-20{ }^{\circ} \mathrm{C}$ until further analysis. Upon thawing, bags were individually rinsed in cold tap water until the effluent was clear, after which bags were frozen $\left(-20^{\circ} \mathrm{C}\right)$, lyophilized, and weighed. Residue remaining in the bag was analyzed for DM, OM, and NDF, and NDF disappearance was calculated. To estimate ME of diets consumed, $48 \mathrm{~h}$ in situ OM digestibility (ISOMD) was used to calculate ME. Conversion of ISOMD to DE was accomplished using the formula of Rittenhouse et al. (1971):

$\mathrm{DE}(\mathrm{Mcal} / \mathrm{kg})=0.039(\% \mathrm{ISOMD})-0.10$,

and $\mathrm{DE}$ was converted to ME using the relationship provided by NRC (2000):

$\mathrm{ME}(\mathrm{Mcal} / \mathrm{kg})=\mathrm{DE}(\mathrm{Mcal} / \mathrm{kg}) \times 0.82$.

Final conversion was to express DE and ME on a MJ/kg basis

$\mathrm{DE}(\mathrm{MJ} / \mathrm{kg})=\mathrm{DE}(\mathrm{Mcal} / \mathrm{kg}) \times 4.184$

$\mathrm{ME}(\mathrm{MJ} / \mathrm{kg})=\mathrm{ME}(\mathrm{Mcal} / \mathrm{kg}) \times 4.184$

\subsection{Statistical analysis}

Experiments were analyzed separately. Pregnancy rate was evaluated using PROC LOGISTIC (SAS Inst. Inc., Cary, NC) procedures with a model that included weaning treatment, cow age and the interaction of weaning treatment and cow age. Cow BW and BCS data were analyzed using Proc MIXED with a model that included weaning treatment, cow age, and the interaction of weaning treatment and cow age. Days postpartum when appropriate were used as covariate. The Random statement was used and included breeding pasture when appropriate. In addition, three preplanned single degree of freedom orthogonal polynomials were used to evaluate the effect of cow age. Tukey-Kramer adjusted least squares means were computed and a significance level was set at $P \leq 0.05$.
A separate analysis was conducted evaluating responses observed to cows receiving weaning treatments for 2 consecutive years (Exp. 1 and 2) on measures obtained in Exp. 2. Data were analyzed the same as above except weaning treatment for both years were tested in the model. Data was unavailable for subsequent year analysis in Exp. 2 due to animals being reassigned to another experiment that manipulated estrous cycles and pregnancy.

\section{Results}

\subsection{Experiment 1}

Breeding season pregnancy rate and conception date ( $d$ into breeding season) were not influenced by weaning treatment $(P>0.54)$ or cow age $(P>0.23)$ at LARRL in 2005 when natural mating occurred without estrous synchronization (Table 2). At the time of normal weaning, cows that had their calves removed at early weaning were in greater body condition $(P<0.01)$, and weighed $15 \mathrm{~kg}$ more $(P<0.01)$ than cows that had their calves removed at normal weaning. Cow BW change $(P<0.01)$ and ADG $(P=0.01)$ throughout the $133-\mathrm{d}$ period from early to normal weaning resulted in a weaning treatment $\times$ cow age interaction (Fig. 2). A decrease in BW and ADG for NW cows was measured as cow age increased whereas similar BW gains were measured for EW cows regardless of cow age. Cows receiving EW treatment gained $0.13 \mathrm{~kg} / \mathrm{d}$, whereas cows assigned the NW treatment lost between 0.36 and $0.51 \mathrm{~kg} /$ $\mathrm{d}$ during the 133-d treatment period between early and normal weaning. The change in BCS over the 133-d period resulted in a 1.0 unit increase $(P<0.01)$ for EW cows compared to NW cows. Cows with calves removed at time of early weaning produced calves that had $2 \mathrm{~kg}$ heavier birth weights $(P=0.01)$ the subsequent year than cows that had calves removed at normal weaning (Table 2). Calving interval was not influenced by weaning treatment $(P=0.87)$ but measured a quadratic $(P<0.01)$ response due to cow age.

Table 2

Least squares means \pm SEM for reproductive and production performance for cows receiving weaning treatments over 133 -d period in 2005 (Exp. 1).

\begin{tabular}{|c|c|c|c|c|c|c|c|c|c|c|c|}
\hline \multirow[b]{2}{*}{ Item $^{\mathrm{a}}$} & \multicolumn{2}{|c|}{ Treatment $^{\mathrm{b}}$} & \multirow[b]{2}{*}{ SEM } & \multirow[b]{2}{*}{$P$-value } & \multicolumn{4}{|c|}{ Cow age } & \multirow[b]{2}{*}{ SEM } & \multirow[b]{2}{*}{$P$-value } & \multirow[b]{2}{*}{ Effect $^{\mathrm{c}}$} \\
\hline & NW & EW & & & 2 & 3 & 4 & $5^{+}$ & & & \\
\hline$n=$ & 118 & 220 & & & 97 & 70 & 104 & 67 & & & \\
\hline \multicolumn{12}{|l|}{ Reproduction } \\
\hline Overall pregnancy (\%) & 92.4 & 94.1 & - & 0.54 & 93.8 & 90.0 & 97.1 & 91.0 & - & 0.23 & - \\
\hline Conception date, $\mathrm{d}$ & 17.4 & 18.1 & 1.00 & 0.60 & 18.7 & 16.2 & 17.0 & 19.0 & 1.40 & 0.37 & - \\
\hline Calf birth weight SY (kg) & 31.2 & 33.2 & 1.23 & 0.01 & 31.2 & 32.2 & 33.6 & 31.9 & 1.45 & 0.07 & - \\
\hline Calving interval (d) & 371 & 371 & 1.68 & 0.87 & 393 & 362 & 367 & 360 & 2.52 & $<0.01$ & $\mathrm{~L}, \mathrm{Q}$ \\
\hline \multicolumn{12}{|l|}{ BW and condition } \\
\hline Cow BW at EW (kg) & 588 & 573 & 5.64 & 0.03 & 500 & 559 & 617 & 646 & 7.63 & $<0.01$ & $\mathrm{~L}, \mathrm{Q}$ \\
\hline Cow BW at NW (kg) & 538 & 597 & 4.95 & $<0.01$ & 504 & 547 & 597 & 622 & 6.72 & $<0.01$ & $\mathrm{~L}$ \\
\hline Cow BW at calving SY (kg) & 562 & 603 & 8.15 & $<0.01$ & 531 & 572 & 609 & 617 & 9.46 & $<0.01$ & $\mathrm{~L}, \mathrm{Q}$ \\
\hline Cow BCS at EW & 6.2 & 6.1 & 0.07 & 0.55 & 5.5 & 6.2 & 6.4 & 6.5 & 0.10 & $<0.01$ & $\mathrm{~L}, \mathrm{Q}$ \\
\hline Cow BCS at NW & 5.3 & 6.3 & 0.12 & $<0.01$ & 5.3 & 5.9 & 6.0 & 6.0 & 0.15 & $<0.01$ & $\mathrm{~L}, \mathrm{Q}$ \\
\hline BCS change (NW-EW) & -1.0 & 0.1 & 0.07 & $<0.01$ & -0.3 & -0.4 & -0.6 & -0.6 & 0.09 & 0.03 & $\mathrm{~L}$ \\
\hline Cow BCS at calving SY & 4.6 & 5.4 & 0.14 & $<0.01$ & 4.5 & 5.1 & 5.3 & 5.1 & 0.17 & $<0.01$ & $\mathrm{~L}, \mathrm{Q}$ \\
\hline
\end{tabular}

a Subsequent year (SY); Body weight (BW); Body condition score (BCS).

b Treatment =Early weaning $(\mathrm{EW})$; Normal weaning $(\mathrm{NW})$.

c Significant $(P \leq 0.05)$ orthogonal polynomials for cow age; Linear (L) and Quadratic (Q). 
In addition, BW and BCS were greater $(P<0.01$; Table 2$)$ for EW treated cows just prior to subsequent year calving compared to cows that received the NW treatment. There was also a quadratic response $(P<0.01)$ for both BW and BCS as cow age increased.

\subsection{Experiment 2}

Artificial insemination pregnancy rate, breeding season pregnancy rate, and day of conception were not different $(P>0.17)$ by weaning treatment or cow age when estrous synchronization was used at the start of breeding (Table 3 ). At the time of normal weaning, cows with calves removed at early weaning weighed $44 \mathrm{~kg}$ more $(P<0.01)$ than cows that had calves removed at normal weaning. In fact, cows with calves removed at time of normal weaning lost BW during the 133-d period between early and normal weaning, whereas cows with calves removed at early weaning gained BW during this same period. Cows that received the early weaning treatment gained $0.13 \mathrm{~kg} / \mathrm{d}$, whereas cows

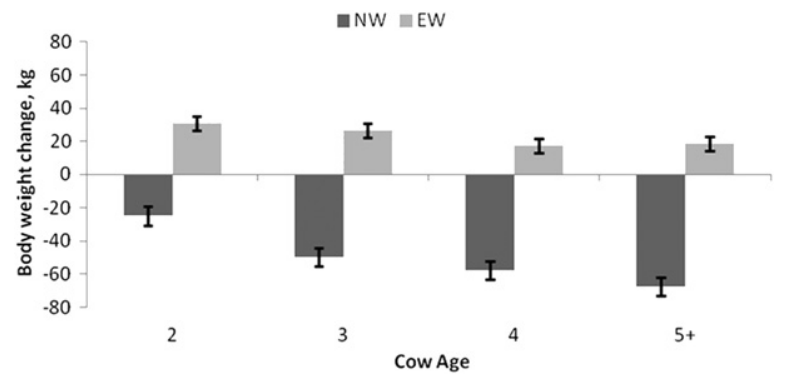

Fig. 2. Least squares means $\pm S E M$ for a weaning treatment $\times$ cow age interaction for body weight change $(P<0.01)$ during a 133-d period between early (EW) and normal weaning (NW) in 2005 (Exp. 1). assigned to the normal weaning treatment lost $0.27 \mathrm{~kg} / \mathrm{d}$ $(P<0.01$; Table 3$)$ during the $133-\mathrm{d}$ treatment period between early and normal weaning. At time of normal weaning, early weaned cows had a 1.3 unit greater BCS $(P<0.01)$ than normal wean treated cows. Body weight and BCS change over the 133-d period favored EW cows $(P<0.01)$. A quadratic response to BW change $(P<0.01)$ over the 133-d indicated that 2-yr-olds maintained BW while 3-yr-olds gained BW and 4-yr-olds and older lost BW. Cows with calves removed at early weaning produced $2 \mathrm{~kg}$ heavier birth weights $(P=0.01)$ the subsequent year than cows that had calves removed at normal weaning (Table 3). Calving interval was not influenced by weaning treatment $(P=0.89)$ but measured a quadratic $(P<0.01)$ response due to cow age. Body weight was greater $(P<0.01)$ for EW treated cows just prior to calving compared to cows that received the NW treatment. There was weaning treatment $\times$ cow age interaction $(P=0.02)$ for pre-calving BCS where all EW cows were in greater BCS than NW cows of similar age; however older cows that received the EW treatment had the greatest BCS (Fig. 3).

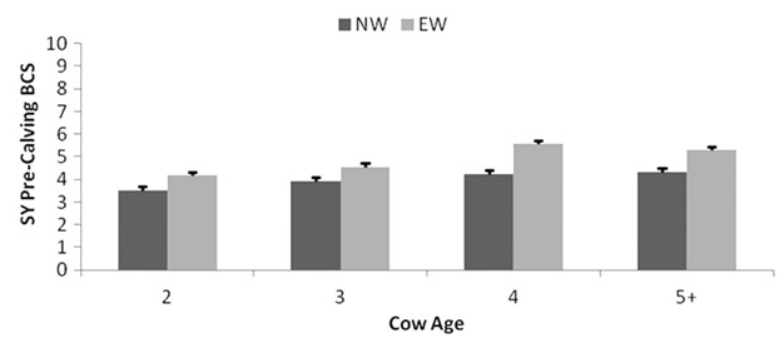

Fig. 3. Least squares means \pm SEM for a weaning treatment $\times$ cow age interaction for subsequent year (SY) pre-calving body condition score (BCS; $P=0.02$ ) between early (EW) and normal weaning (NW) in 2006 (Exp. 2).

Table 3

Least squares means \pm SEM for reproductive and production performance for cows receiving weaning treatments over 133 -d period in 2006 (Exp. 2).

\begin{tabular}{|c|c|c|c|c|c|c|c|c|c|c|c|}
\hline \multirow[b]{2}{*}{ Item $^{\mathrm{a}}$} & \multicolumn{2}{|c|}{ Treatment $^{\mathrm{b}}$} & \multirow[b]{2}{*}{ SEM } & \multirow[b]{2}{*}{$P$-value } & \multicolumn{4}{|c|}{ Cow age } & \multirow[b]{2}{*}{ SEM } & \multirow[b]{2}{*}{$P$-value } & \multirow[b]{2}{*}{ Effect $^{\mathrm{C}}$} \\
\hline & NW & EW & & & 2 & 3 & 4 & $5^{+}$ & & & \\
\hline$n=$ & 107 & 215 & & & 88 & 72 & 47 & 115 & & & \\
\hline \multicolumn{12}{|l|}{ Reproduction } \\
\hline AI pregnancy (\%) & 55.1 & 60.5 & - & 0.36 & 52.3 & 63.9 & 61.7 & 59.1 & - & 0.48 & - \\
\hline NW & - & - & - & & 40.0 & 56.5 & 81.3 & 55.3 & - & & - \\
\hline EW & - & - & - & & 58.6 & 67.4 & 51.6 & 61.0 & - & & - \\
\hline Overall pregnancy (\%) & 93.5 & 96.7 & - & 0.17 & 93.2 & 95.8 & 97.9 & 96.5 & - & 0.56 & - \\
\hline Conception date (d) & 11.4 & 12.3 & 1.40 & 0.59 & 14.2 & 9.8 & 11.9 & 11.5 & 2.07 & 0.30 & - \\
\hline Calf birth weight SY $(\mathrm{kg})$ & 39.4 & 41.4 & 0.92 & $<0.01$ & 40.1 & 39.9 & 40.0 & 41.6 & 1.32 & 0.12 & - \\
\hline Calving interval $(\mathrm{d})$ & 377 & 377 & 2.07 & 0.89 & 401 & 365 & 372 & 369 & 3.07 & $<0.01$ & $\mathrm{~L}, \mathrm{Q}$ \\
\hline \multicolumn{12}{|l|}{ BW and condition } \\
\hline Cow BW at EW (kg) & 546 & 537 & 4.90 & 0.15 & 463 & 529 & 570 & 606 & 7.42 & $<0.01$ & $\mathrm{~L}, \mathrm{Q}$ \\
\hline Cow BW at NW (kg) & 512 & 556 & 4.64 & $<0.01$ & 464 & 531 & 558 & 582 & 7.01 & $<0.01$ & $\mathrm{~L}, \mathrm{Q}$ \\
\hline Cow BW change (kg) & -36.1 & 16.4 & 3.11 & $<0.01$ & -0.2 & 0.8 & -14.6 & -25.5 & 4.55 & $<0.01$ & $\mathrm{~L}, \mathrm{Q}$ \\
\hline $\mathrm{ADG}(\mathrm{kg} / \mathrm{d})$ & -0.27 & 0.13 & 0.02 & $<0.01$ & -0.01 & 0.01 & -0.11 & -0.19 & 0.04 & $<0.01$ & $\mathrm{~L}, \mathrm{Q}$ \\
\hline Cow BW at calving SY (kg) & 543 & 582 & 4.95 & $<0.01$ & 492 & 561 & 587 & 610 & 7.34 & $<0.01$ & $\mathrm{~L}, \mathrm{Q}$ \\
\hline Cow BCS at EW & 4.4 & 4.4 & 0.08 & 0.83 & 3.9 & 3.9 & 4.9 & 4.8 & 0.12 & $<0.01$ & $\mathrm{~L}$ \\
\hline Cow BCS at NW & 4.1 & 5.4 & 0.07 & $<0.01$ & 4.3 & 4.5 & 5.1 & 5.1 & 0.10 & $<0.01$ & $\mathrm{~L}$ \\
\hline BCS change (NW-EW) & -0.2 & 1.3 & 0.13 & $<0.01$ & 0.5 & 0.9 & 0.4 & 0.5 & 0.18 & 0.01 & - \\
\hline
\end{tabular}

a Subsequent year (SY); Body weight (BW); Body condition score (BCS).

b Treatment=Early weaning $(\mathrm{EW})$; Normal weaning $(\mathrm{NW})$.

c Significant $(P \leq 0.05)$ orthogonal polynomials for cow age; Linear (L) and Quadratic (Q). 
Cows in Exp. 2 that had also received weaning treatment the previous year (Exp. 1) had similar AI pregnancy rates $(P=0.16$; Table 4$)$. Furthermore, overall pregnancy rate, conception date, and calving interval were not influenced by weaning treatment combination (Exp. 1 and 2) or cow age. There was a tendency $(P=0.09)$ for EW cows in Exp. 2 that also received the EW weaning treatment in Exp. 1 to have heavier calf birth weights the subsequent year (Table 4). Cow BW and BCS was greater $(P<0.01)$ for cows that received the EW treatment in both Exp. 1 and 2. An interaction between weaning treatments $\times$ cow age for BW change $(P=0.04)$ during the 133-d period indicated that younger cows respond more favorably to EW whereas older cows were more negatively influenced by having calves that remained suckling until time of normal weaning (Fig. 4).

\subsection{Experiment 3}

Cows receiving the early weaning treatment had $12.0 \%$ greater $(P=0.03)$ AI pregnancy rate and conceived $3.8 \mathrm{~d}$ earlier $(P=0.03)$ than cows receiving the normal weaning treatment (Table 5). Overall breeding season pregnancy rates tended to be greater $(P=0.07)$ for early wean treated cows compared to normal wean treated cows. Subsequent year calf birth weights were similar $(P=0.96)$ for weaning treatments and increased linearly $(P \leq 0.05)$ as cow age increased. Body weight for EW cows was $37 \mathrm{~kg}$ heavier $(P<0.01)$ than NW cows at the time of normal weaning. Body weight change and ADG throughout the 133-d period resulted in a weaning treatment $\times$ cow age interaction $(P<0.01)$. All cows gained BW regardless of cow weaning treatment; however, early wean treated cows gained more BW and 2-yr-old NW treated cows gaining substantially less BW than 2-yr-old EW treated cows resulting in the interaction (Fig. 5).

\section{Discussion}

The authors were surprised that breeding performance was not improved for cows that had their calves removed at time of early weaning (start of breeding) in Exp. 1. This was especially surprising since cow size (weight and height) and milk production have generally increased (Dib et al., 2010; Northcutt and Wilson, 1993) in beef cattle since earlier reports by others (Laster et al., 1973; Lusby et al., 1981). Therefore, removal of the demands of lactation should favor reproduction and may have under more extreme environmental constraints then those experienced in the present study. Early weaning in Exp. 1 was applied at the start of breeding rather than $8 \mathrm{~d}$ prior to breeding (Laster et al., 1973) or early weaned 6-8 weeks

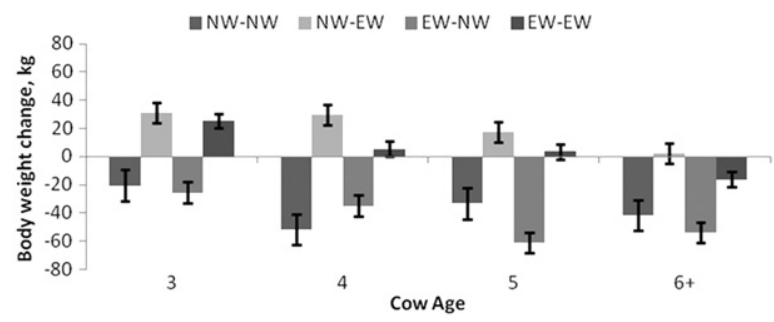

Fig. 4. Least squares means \pm SEM for body weight change for cows receiving weaning treatments for 2 consecutive years (Exp. 1 and 2) an interaction of weaning treatments $\times$ cow age interaction $(P=0.04)$ during the 133-d period between early (EW) and normal weaning (NW).

Table 4

Least squares means \pm SEM for reproductive and production performance for cows that received weaning treatments in both Exp. 1 (2005) and 2 (2006)

\begin{tabular}{|c|c|c|c|c|c|c|c|c|c|c|c|c|c|}
\hline \multirow[b]{2}{*}{ Item $^{\mathrm{a}}$} & \multicolumn{4}{|c|}{ Treatment $^{\mathrm{b}}$} & \multirow[b]{2}{*}{ SEM } & \multirow[b]{2}{*}{$P$-value } & \multicolumn{4}{|c|}{ Cow age } & \multirow[b]{2}{*}{ SEM } & \multirow[b]{2}{*}{$P$-value } & \multirow[b]{2}{*}{ Effect $^{\mathrm{C}}$} \\
\hline & NW-NW & NW-EW & EW-NW & EW-EW & & & 3 & 4 & 5 & $6^{+}$ & & & \\
\hline$n=$ & 33 & 52 & 44 & 103 & & & 71 & 46 & 76 & 39 & & & \\
\hline \multicolumn{14}{|l|}{ Reproduction } \\
\hline AI pregnancy (\%) & 48.5 & 55.8 & 70.5 & 65.1 & - & 0.16 & 64.8 & 63.0 & 60.5 & 56.4 & - & 0.84 & - \\
\hline NW-NW & & & & & & & 36.4 & 83.3 & 41.7 & 50.0 & & & \\
\hline NW-EW & & & & & & & 66.7 & 50.0 & 50.0 & 55.6 & & & \\
\hline EW-NW & & & & & & & 75.0 & 80.0 & 61.5 & 66.7 & & & \\
\hline EW-EW & & & & & & & 69.7 & 56.3 & 70.3 & 52.9 & & & \\
\hline Overall pregnancy (\%) & 93.9 & 98.1 & 93.2 & 98.1 & - & 0.36 & 95.8 & 97.8 & 94.7 & 100.0 & - & 0.48 & - \\
\hline Conception date (d) & 13.9 & 12.3 & 7.8 & 11.8 & 1.97 & 0.20 & 9.3 & 12.0 & 11.2 & 13.2 & 2.29 & 0.53 & - \\
\hline Calf birth BW SY (kg) & 41.5 & 42.8 & 41.1 & 43.5 & 1.47 & 0.09 & 41.0 & 41.9 & 42.9 & 43.1 & 1.60 & 0.21 & $\mathrm{~L}$ \\
\hline Calving interval $(\mathrm{d})$ & 370 & 369 & 363 & 368 & 4.56 & 0.41 & 363 & 370 & 365 & 373 & 4.50 & 0.15 & - \\
\hline \multicolumn{14}{|l|}{ BW and condition } \\
\hline Cow BW at EW (kg) & 576 & 550 & 588 & 588 & 9.69 & $<0.01$ & 527 & 570 & 597 & 607 & 9.19 & $<0.01$ & L, Q \\
\hline Cow BW at NW (kg) & 539 & 570 & 545 & 592 & 9.32 & $<0.01$ & 530 & 557 & 579 & 579 & 8.83 & $<0.01$ & $\mathrm{~L}$ \\
\hline ADG $(\mathrm{kg} / \mathrm{d})$ & -0.28 & 0.17 & -0.33 & 0.04 & 0.03 & $<0.01$ & 0.03 & -0.09 & -0.13 & -0.21 & 0.03 & $<0.01$ & $\mathrm{~L}$ \\
\hline Cow BW at calving SY (kg) & 580 & 602 & 567 & 619 & 9.90 & $<0.01$ & 559 & 587 & 606 & 616 & 9.25 & $<0.01$ & $\mathrm{~L}$ \\
\hline Cow BCS at EW & 4.3 & 4.2 & 4.8 & 4.8 & 0.15 & $<0.01$ & 3.8 & 4.8 & 4.7 & 4.6 & 0.15 & $<0.01$ & $\mathrm{~L}, \mathrm{Q}$ \\
\hline Cow BCS at NW & 4.2 & 5.5 & 4.3 & 5.6 & 0.10 & $<0.01$ & 4.5 & 5.1 & 5.2 & 4.9 & 0.12 & $<0.01$ & $\mathrm{~L}, \mathrm{Q}$ \\
\hline BCS change (NW-EW) & 0.1 & 1.8 & -0.3 & 1.3 & 0.21 & $<0.01$ & 1.0 & 0.6 & 0.8 & 0.5 & 0.22 & 0.03 & $\mathrm{~L}$ \\
\hline Cow BCS at calving SY & 4.1 & 4.9 & 4.0 & 5.2 & 0.17 & $<0.01$ & 4.2 & 4.8 & 4.7 & 4.3 & 0.18 & $<0.01$ & $\mathrm{~L}, \mathrm{Q}$ \\
\hline
\end{tabular}

a Subsequent year (SY); Body weight (BW); Body condition score (BCS).

b Treatment=Early weaning (EW); Normal weaning (NW) for Exp. 1 (2005) and Exp. 2 (2006), respectively.

c Significant $(P \leq 0.05)$ orthogonal polynomials for cow age; Linear (L) and Quadratic (Q). 
Table 5

Least squares means \pm SEM for reproductive and production performance for cows receiving weaning treatments over 133 -d period in 2005 (Exp. 3)

\begin{tabular}{|c|c|c|c|c|c|c|c|c|c|c|c|}
\hline \multirow[b]{2}{*}{ Item $^{\mathrm{a}}$} & \multicolumn{2}{|c|}{ Treatment $^{\mathrm{b}}$} & \multirow[b]{2}{*}{ SEM } & \multirow[b]{2}{*}{$P$-value } & \multicolumn{4}{|c|}{ Cow age } & \multirow[b]{2}{*}{ SEM } & \multirow[b]{2}{*}{$P$-value } & \multirow[b]{2}{*}{ Effect $^{\mathrm{C}}$} \\
\hline & NW & EW & & & 2 & 3 & 4 & $5^{+}$ & & & \\
\hline$n=$ & 121 & 236 & & & 92 & 62 & 60 & 143 & & & \\
\hline \multicolumn{12}{|l|}{ Reproduction } \\
\hline AI pregnancy (\%) & 53.3 & 65.3 & - & 0.03 & 62.0 & 64.5 & 63.3 & 58.5 & - & 0.83 & - \\
\hline NW & - & - & - & & 53.6 & 56.5 & 52.6 & 52.0 & - & & - \\
\hline EW & - & - & - & & 65.6 & 69.2 & 68.3 & 62.0 & - & & - \\
\hline Overall pregnancy (\%) & 87.5 & 93.2 & - & 0.07 & 91.3 & 95.2 & 93.3 & 88.7 & - & 0.45 & - \\
\hline Conception date $(\mathrm{d})$ & 12.2 & 8.4 & 1.41 & 0.03 & 10.0 & 9.8 & 11.8 & 9.7 & 1.99 & 0.84 & - \\
\hline Calf birth weight SY (kg) & 40.4 & 40.3 & 0.57 & 0.96 & 39.1 & 40.7 & 40.2 & 41.4 & 1.09 & 0.04 & $\mathrm{~L}$ \\
\hline Calving interval (d) & 371 & 369 & 1.64 & 0.24 & 389 & 366 & 360 & 364 & 2.35 & $<0.01$ & $\mathrm{~L}, \mathrm{Q}$ \\
\hline \multicolumn{12}{|l|}{ Body weight } \\
\hline Cow BW at EW (kg) & 544 & 535 & 4.72 & 0.13 & 471 & 532 & 563 & 592 & 4.25 & $<0.01$ & L, Q \\
\hline Cow BW at NW (kg) & 581 & 618 & 5.21 & $<0.01$ & 558 & 575 & 617 & 647 & 7.51 & $<0.01$ & $\mathrm{~L}$ \\
\hline
\end{tabular}

a Subsequent year (SY); Body weight (BW); Body condition score (BCS).

b Treatment=Early weaning $(\mathrm{EW})$; Normal weaning $(\mathrm{NW})$.

c Significant $(P \leq 0.05)$ orthogonal polynomials for cow age; Linear (L) and Quadratic (Q).

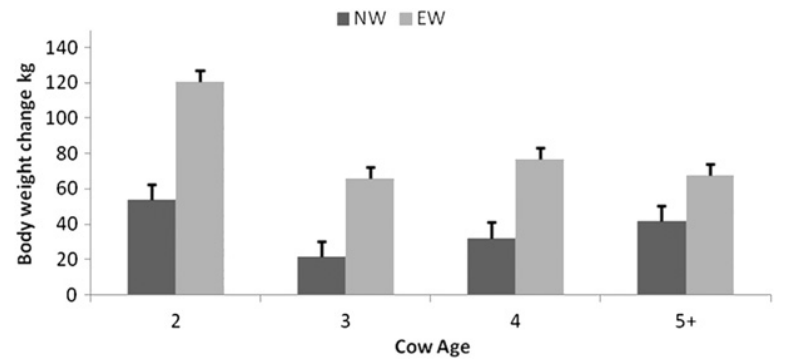

Fig. 5. Least squares means \pm SEM for a weaning treatment $\times$ cow age interaction for body weight change $(P<0.01)$ during a 133-d period between early (EW) and normal weaning (NW) in 2005 (Exp. 3).

after parturition which was approximately $22 \mathrm{~d}$ prior to breeding (Lusby et al., 1981). The excellent body condition of cows in Exp. 1 at onset of breeding coupled with availability of high quality forage early in breeding season may have masked reproductive responses in the present study.

Effects of permanent weaning at the start of an estrous synchronized breeding season (Exp. 2 and 3) that used protocols capable of inducing cyclicity in cows are absent in the literature. While early weaning did not improve AI or breeding season pregnancy rates in Exp. 2, it is noteworthy that among 2-yr and 3-yr-old early wean treated cows there was a $19 \%$ and $11 \%$ numerical increase in pregnancy rates compared to cows that had their calves removed at normal weaning. Previously reported research supports the potential for increased pregnancy rates of young cows following early weaning (Laster et al., 1973; Myers et al., 1999a). Temporary 48-h calf removal just before breeding has also been reported to increase AI pregnancy rate (Geary et al., 2001; Kiser et al., 1980; Smith et al., 1979). It is possible that the estrous synchronization protocol used in the current study may have masked the benefits of early weaning because of its ability to induce estrous cycles in anestrous cows (Lamb et al., 2001; Lucy et al., 2001; Twagiramungu et al., 1995).
In Exp. 3, more early weaned cows conceived to AI $(P>0.05)$ than normal weaned cows. The improved fertility in this herd, even though the same estrous synchronization protocol was used in Exp. 3 as was used in Exp. 2, is unclear, but suggests that the potential for improved breeding performance exists. However, the reproductive performance of cows in Exp. 1 and 2 (especially older cows) demonstrates that a beneficial effect of early weaning on reproduction does not always occur.

In Exp. 1, 2, and 3, breeding occurred coincident with availability of high quality forage. Precipitation was near normal for all three experiments (Fig. 1). Thus, forage quality and quantity (Table 1) were not considered limiting for mature cows in the environments in which this research was conducted. Forage extrusa characteristics were consistent across both years at LARRL. Forage NDF increased and digestibility decreased from time of early weaning to normal weaning. However, forage digestibility was less in Exp. 2 which was reflected in the BW measurements (Table 3). The losses of BW and BCS observed in Exp. 1 and 2 between the times of early and normal weaning for NW treated cows is typical for this herd and suggests not all requirements were met for lactating cows between early July and mid-November. Typically, as summer progresses, temperatures increase while precipitation decreases, followed by decreases in forage quality that continue through fall and winter, negatively impacting livestock production (Adams and Short, 1988). Furthermore, interannual variation in timing and amount of precipitation received accompanied with variable ambient temperatures greatly influence forage production (Grings et al., 2005; Sims and Singh, 1978a,b). In Exp. 3, cows calved earlier in the year and both EW and NW treated cows gained BW during the 133-d time period between early and normal weaning.

Cows subjected to early weaning either maintained or increased in BCS compared to normal wean treated cows throughout the 133-d period in Exp. 1 and 2, respectively. Compared to their cohorts who nursed until the time of 
normal weaning, these cows had an advantage of 1 BCS at time of normal weaning. We were unable to collect body condition scores of cows in Exp. 3. However, Corah et al. (1991) estimated that a $34 \mathrm{~kg}$ difference in weight corresponded to one body condition score. Thus at the time of normal weaning, EW treated cows in Exp. 3 may have also had an approximately 1.1 BCS advantage over NW treated contemporaries. This consistent advantage in BCS for cows subjected to early weaning should allow them to arrive at calving in a more favorable BCS with less supplemental feed during winter than normal weaned contemporaries. Improved weight gains from early weaning reported by Galindo-Gonzalez et al., (2007), Lusby et al. (1981), and Myers et al. (1999b) are similarly interpreted to confer an advantage in body condition.

In Exp. 1 and 2, cows subjected to early weaning treatment had heavier calves at birth the subsequent year than cows that received normal weaning treatment the previous year. This difference was not observed in Exp. 3. Following the rationale above, the nutritional environment (i.e., forage quality) at LARRL may have been inadequate to meet all requirements between early July and mid-November whereas Judith Gap cows were an earlier calving herd. Thus, the imposed early weaning treatment allowed nutrients used to support lactation to be repartitioned towards maternal tissues, such as reproduction, in the nursing cows at LARRL, and consequently benefit endocrine mechanisms that influence uptake and utilization of nutrients by the conceptus (Robinson et al., 1999). Furthermore, prior to calving, cows that received the early weaning treatment in Exp. 1 and 2 were in greater BW and BCS indicating a greater capacity to endure parturition, rebound through uterine involution, and regain reproductive competency (Rae et al., 1993).

\section{Conclusion}

When initiating this research, potential for an interaction between the weaning treatment effects and cow age of the cows was anticipated with early weaning being potentially more advantageous for younger cows. This interaction was not consistently detected. Thus, at least under these conditions, effects of early weaning were independent of cow age.

Early weaning calves can increase the opportunity for cows to gain weight and improve body condition before winter. This may facilitate over-wintering cows using less harvested feedstuffs. Under some circumstances, early weaning may also increase the likelihood of the cow becoming pregnant early in the breeding season.

\section{Conflict of interest statement}

Research was funded by the United States Department of Agriculture, Agricultural Research Service (Project \# 5434-31000-014-00D). The authors declare there are no conflicts of interest.

\section{Acknowledgments}

The authors gratefully acknowledge W. Kelly, R.P. Ansotegui, C. Molle, M. Woods, and S. Bellows for their technical assistance and Dean and Trudi Petersen (Judith Gap, MT 59453, USA) for providing cattle for use in this study. The authors also wish to acknowledge Teva Animal Health, St. Joseph, MO 64503, USA for their support of this project. The authors would also like to express their gratitude to the Montana Beef Network for partial funding (early weaning feed for Judith Gap, MT 59453, USA) of this project.

\section{References}

Adams, D.C., Short, R.E., 1988. The role of animal nutrition on productivity in a range environment. In: White, R.S., Short, R.E. (Eds.) Achieving Efficient Use of Rangeland Resources, Fort Keogh Res. Symp., Miles City, MT, pp. 37-45.

AOAC, 1990. Official Methods of Analysis, 15th ed. Association of Official Analytical Chemists. Arlington, VA, USA.

Corah, L.R., Lemenager, R.P., Houghton, P.L., Blasi, D.A., 1991. Feeding your cows by body condition. Kansas Cooperative Extension Service. Kansas State University, Manhattan, KS (C-842).

Dib, M.G., Van Vleck, L.D., Spangler, M.L., 2010. Genetic analysis of mature size in American Angus cattle. Nebraska Beef Rep., 29-30.

Galindo-Gonzalez, S., Arthington, J.D., Yelich, J.V., Hansen, G.R., Lamb, G.C., De Vries, A., 2007. Effects of cow parity on voluntary hay intake and performance responses to early weaning of beef calves. Livest. Sci. 110, 148-153.

Geary, T.W., Whittier, J.C., Hallford, D.M., MacNeil, M.D., 2001. Calf removal improves conception rates to the Ovsynch and CO-Synch protocols. J. Anim. Sci. 79, 1-4.

Goering, H.K., Van Soest, P.J., 1970. Forage fiber analyses (apparatus, reagents, procedures, and some applications), Agriculture Handbook USDA-ARS, Washington, DC.

Grings, E.E., Short, R.E., Klement, K.D., Geary, T.W., MacNeil, M.D., Haferkamp, M.R., Heitschmidt, R.K., 2005. Calving system and weaning age effects on cow and preweaning calf performance in the Northern Great Plains. J. Anim. Sci. 83, 2671-2683.

Hansen, P.J., Baik, D.H., Rutledge, J.J., Hauser, E.R., 1982. Genotype $\times$ environmental interactions on reproductive traits of bovine females. II. Postpartum reproduction as influenced by genotype, dietary regimen, level of milk production and parity. J. Anim. Sci. 55 1458-1472.

Herd, D.H., Sprott, L.R., 1986. Body condition, nutrition and reproduction of beef cows. Texas Agric. Extension Serv. B-1526, 1-11.

Johnson, C.R., Lalman, D.L., Brown, M.A., Appeddu, L.A., Buchanan, D.S. Wettemann, R.P., 2003. Influence of milk production potential on forage dry matter intake by multiparous and primiparous Brangus females. J. Anim. Sci. 81, 1837-1846.

Kiser, T.E., Dunlap, S.E., Benyshek, L.L., Mares, S.E., 1980. The effect of calf removal on estrous response and pregnancy rate of beef cows after Syncro-Mate-B treatment. Theriogenology 13, 381-389.

Küchler, A.W., 1964. Potential Natural Vegetation of the Coterminous United States. American Geographical Society, New York, NY, USA.

Lamb, G.C., Stevenson, J.S., Kesler, D.J., Garverick, H.A., Brown, D.R., Salfen, B.E., 2001. Inclusion of an intravaginal progesterone insert plus GnRH and prostaglandin F2alpha for ovulation control in postpartum suckled beef cows. J. Anim. Sci. 79, 2253-2259.

Laster, D.B., Glimp, H.A., Gregory, K.E., 1973. Effects of early weaning on postpartum reproduction of cows. J. Anim. Sci. 36, 734-740.

Lesperance, A.L., Bohman, V.R., Marble, D.W., 1960. Development of techniques for evaluating grazed forage. J. Dairy Sci. 43, 682-689.

Lucy, M.C., Billings, H.J., Butler, W.R., Ehnis, L.R., Fields, M.J., Kesler, D.J. Kinder, J.E., Mattos, R.C., Short, R.E., Thatcher, W.W., Wettemann, R.P., Yelich, J.V., Hafs, H.D., 2001. Efficacy of an intravaginal progesterone insert and an injection of PGF2alpha for synchronizing estrus and shortening the interval to pregnancy in postpartum beef cows, peripubertal beef heifers, and dairy heifers. J. Anim. Sci. 79, 982-995.

Lusby, K.S., Wettemann, R.P., Turman, T.E., 1981. Effects of early weaning calves from first-calf heifers on calf and heifer performance. J. Anim. Sci. 53, 1193-1197.

Marston, T.T., Lusby, K.S., 1995. Effects of energy or protein supplements and stage of production on intake and digestibility of hay by beef cows. J. Anim. Sci. 73, 651-656. 
Mortenson, M.C., 2003. Effects of interseeded alfalfa (Medicago sativa ssp. falcata) on forage production, forage quality, and carbon sequestration on a mixed-grass rangeland. M.S. Thesis, University of Wyoming, Laramie.

Myers, S.E., Faulkner, D.B., Ireland, F.A., Berger, L.L., Parrett, D.F., 1999a. Production systems comparing early weaning to normal weaning with or without creep feeding for beef steers. J. Anim. Sci. 77, 300-310.

Myers, S.E., Faulkner, D.B., Ireland, F.A., Parrett, D.F., 1999b. Comparison of three weaning ages on cow-calf performance and steer carcass traits. J. Anim. Sci. 77, 323-329.

Northcutt, S.L., Wilson, D.E., 1993. Genetic parameter estimates and expected progeny differences for mature size in Angus cattle. J. Anim. Sci. 71, 1148-1153.

NRC, 2000. Nutrient Requirements of Beef Cattle, 7th revised ed. National Academy Press, Washington, DC.

Rae, D.O., Kunkle, W.E., Chenoweth, P.J., Sand, R.S., Tran, T., 1993. Relationship of parity and body condition score to pregnancy rates in Florida beef cattle. Theriogenology 39, 1143-1152.

Rittenhouse, L.R., Streeter, C.L., Clanton, D.C., 1971. Estimating digestible energy from digestible dry and organic matter in diets of grazing cattle. J. Range Manage. 24, 73-75.

Robinson, J.J., Sinclair, K.D., McEvoy, T.G., 1999. Nutritional effects on foetal growth. Anim. Sci. 68, 315-331.

Short, R.E., Bellows, R.A., Moody, E.L., Howland, B.E., 1972. Effects of suckling and mastectomy on bovine postpartum reproduction. J. Anim. Sci. 34, 70-74.
Sims, P.L., Singh, J.S., 1978a. The structure and function of ten western North American grasslands. II. Intra-seasonal dynamics in primary producer compartments. J. Ecol. 66, 547-572.

Sims, P.L., Singh, J.S., 1978b. The structure and function of ten western North American grasslands. III. Net primary production, turnover and efficiencies of energy capture and water use. J. Ecol. 66, 573-597.

Smith, M.F., Burrell, W.C., Shipp, L.D., Sprott, L.R., Songster, W.N., Wiltbank, J.N., 1979. Hormone treatments and use of calf removal in postpartum beef cows. J. Anim. Sci. 48, 1285-1294.

Twagiramungu, H., Guilbault, L.A., Dufour, J.J., 1995. Synchronization of ovarian follicular waves with a gonadotropin-releasing hormone agonist to increase the precision of estrus in cattle: a review. J. Anim. Sci. 73, 3141-3151.

Wagner, J.J., Lusby, K.S., Oltjen, J.W., Rakestraw, J., Wettemann, R.P., Walters, L.E., 1988. Carcass composition in mature Hereford cows: estimation and effect on daily metabolizable energy requirement during winter. J. Anim. Sci. 66, 603-612.

Waterman, R.C., Grings, E.E., Geary, T.W., Roberts, A.J., Alexander, L.J., MacNeil, M.D., 2007. Influence of seasonal forage quality on glucose kinetics of young beef cows. J. Anim. Sci. 85, 2582-2595.

WRCC, 2006. Western U.S. Climate Historical Summaries. Available: $\langle$ http://www.wrcc.dri.edu/climsum.html $\rangle$. Accessed March 20, 2006. 